\title{
PENGARUH EDUKASI GIZI MELALUI MEDIA VIDEO PIRING MAKANKU TERHADAP PENGETAHUAN DAN SIKAP SISWA
}

\author{
Sutrio $^{1}$ dan Andi Eka Yunianto 2 \\ ${ }^{1}$ Jurusan Gizi, Politeknik Kesehatan Kementerian Kesehatan (Poltekkes Kemenkes) Tanjung Karang \\ Jl. Soekarno - Hatta No.1, Hajimena, Kec. Natar, Kabupaten Lampung Selatan - Indonesia \\ ${ }^{2}$ Program Studi Gizi, Fakultas Ilmu Kesehatan, Universitas Siliwangi \\ Jl. Siliwangi No.24 Kota Tasikmalaya, Jawa Barat - Indonesia \\ Email : sutrio.syakir@yahoo.com
}

\begin{tabular}{l} 
Article Info \\
\hline Article history: \\
Received January $14^{\text {th }}, 2021$ \\
Revised February $21^{\text {th }}, 2021$ \\
Accepte March $25^{\text {th }}, 2021$ \\
\hline
\end{tabular}

Keyword:

Attitudes; Knowledge; Nutrition Education; Students; Video

\section{Kata Kunci :}

Edukasi Gizi; Pengetahuan; Sikap; Siswa; Video

\begin{abstract}
Background : The problem of nutrition in adolescents, especially the problem of obesity, is one of the focuses of government attention. Nutrition education is one of the most effective ways to increase the knowledge and attitudes of adolescents to maintain their diet so that obesity does not occur.
\end{abstract}

Purpose : This study purposed to analyze the effectiveness of nutrition education in the video media "Piring Makanku" towards increasing the knowledge and attitudes of students at SMP Negeri 1 Tumijajar.

Methods : The design in this study was a quasi-experiment. The sample in this study amounted to 30 students of class IX through random sampling divided into 2 groups, namely intervention and control. The Mann-Whitney test was used to analyze differences in the effectiveness of nutrition education on students' knowledge and attitudes.

Results : The education provided was able to increase students' knowledge $(p=0.001)$ and attitudes $(p=0.001)$ in both the intervention group and the control group.

Conclusion : Nutrition education is effective in increasing students' knowledge and attitudes.

\begin{abstract}
ABSTRAK
Latar Belakang : Masalah gizi pada remaja terutama masalah kegemukan menjadi salah satu fokus perhatian pemerintah. Edukasi gizi adalah salah satu cara yang yang efektif dalam meningkatkan pengetahuan dan sikap remaja untuk menjaga pola makan agar tidak terjadi kegemukan.

Tujuan : Penelitian ini bertujuan untuk menganalisis efektifitas edukasi gizi media video "Piring Makanku" terhadap peningkatan pengetahuan dan sikap siswa di SMP Negeri 1 Tumijajar.

Metode : Desain penelitian ini adalah quasi experiment. Sampel pada penelitian ini berjumlah 30 siswa kelas IX dengan cara random sampling yang terbagi 2 kelompok yaitu intervensi dan kontrol. Uji Mann-Whitney digunakan untuk menganalisis perbedaan efektivitas edukasi gizi terhadap pengetahuan dan sikap siswa.
\end{abstract}

Hasil : Edukasi yang diberikan dapat meningkatkan pengetahuan $(p=0,001)$ dan sikap $(p=0,001)$ siswa baik pada kelompok intervensi 
dan kelompok kontrol.

Kesimpulan : Pemberian edukasi gizi melalui media video berpengaruh terhadap meningkatan pengetahuan dan sikap siswa.

\section{PENDAHULUAN}

Obesitas merupakan suatu masalah yang dihadapi di berbagai negara di dunia. Obesitas menyebabkan masalah kesehatan yang serius di masyarakat serta meberikan peningkatan biaya perawatan kesehatan. Hal tersebut dikarenakan bahwa obesitas merupakan faktor risiko independen dan secara signifikan meningkatkan risiko morbiditas dan mortalitas (Lindberg et al., 2020). Obesitas pada remaja terutama anak usia sekolah usia 5-15 tahun telah meningkatkan serum lipid, tekanan darah, glukosa, dan insulin yang menjadi penyebab penyakit degeneratif dan gangguan metabolik di usia dewasa seperti hipertensi, diabetes, stroke, dan jantung (Hudson and Viner, 2012).

Masalah gizi lebih pada remaja lebih banyak terjadi pada usia $\geq 15$ tahun dan selalu terjadi peningkatan berdasarkan data riset kesehatan dasar tahun 2013 dan tahun 2018 terjadi peningkatan prevalensi obesitas dari 26,6\% menjadi 31,0\% (Kemenkes RI, 2014a, 2019). Prevalensi gizi lebih pada remaja usia $\geq 15$ tahun di Provinsi Lampung sebesar 25,1\% mendekati angka nasional yaitu sebesar $31 \%$. Perubahan gaya hidup masyarakat dari pola makan tradisional kearah western food yang tinggi akan karbohidrat dan lemak membuat obesitas pada remaja trennya merangkak naik. Berdasarkan Studi Diet Total (SDT) Tahun 2014 menunjukan bahwa rata-rata konsumsi lemak remaja usia 13 - 18 tahun tertinggi dari kelompok umur lain sebesar 30,3\% sedangkan konsumsi garam dan gula sebesar 25,9\% dan 2\%. Hal ini disertai konsumsi buah dan sayur yang rendah yaitu 45,8 gram dan 25,2 gram per hari (Kemenkes RI, 2014b).

Pengetahuan merupakan salah satu faktor penentu bagi siswa dalam memilih makanan yang tepat dalam pola makan sehari-hari (Epuru and Shammary, 2014). Pengetahuan yang baik akan berpengaruh terhadap sikap seseorang dalam memilih makanan yang lebih sehat untuk dikonsumsi(Weerasekara et al., 2020). Pengetahuan gizi berinteraksi dengan evaluasi kesehatan makanan untuk mempengaruhi sikap makanan. Sikap akan memandu perilaku siswa dalam memilih makanan yang lebih sehat dan bergizi (Crites and Aikman, 2005). Penelitian sebelumnya menemukan bahwa tingkat pengetahuan gizi remaja berhubungan dengan kejadian obesitas pada remaja. Pengetahuan gizi yang rendah pada remaja membuat mereka mengkonsumsi makanan yang tidak sehat sehingga menimbulkan masalah kegemukan (Shahsanai et al., 2018; Asmuniati, Herawati and Djais, 2019).

Penalataksanaan obesitas meliputi tiga aspek yaitu pengaturan sikap, peningkatan aktifitas fisik, dan edukasi. Edukasi gizi dapat membantu meningkatkan pengetahuan dan sikap tentang praktik perilaku hidup sehat melalui pemilihan dan perilaku makan kea rah yang lebih baik (Darawati, 2020). Edukasi gizi dengan bantuan media yang menarik dapat mempermudah remaja memahami materi dengan baik. Pemilihan media yang tepat juga membantu siswa lebih membangkitkan siswa dalam belajar (Kamsiah, 2020). Salah satu media edukasi yang menarik untuk siswa dalam belajar mengenai pedoman gizi seimbang yaitu video.

Video yang disematkan dapat meningkatkan proses pendidikan dan dapat menjadi cara untuk meningkatkan retensi jangka panjang informasi nutrisi pada remaja(Ajie, Muzaffar and Chapman-Novakofski, 2014). Media video lebih efektif meningkatkan pengetahuan gizi siswa disekolah dibandingkan dengan menggunakan media power point (Febriana, Devi Artanti and Rusilanti, 2020). Video merupakan media audio visual telah berhasil membangkitkan ketertarikan dan membangkitkan rasa kemandirian siswa sehingga partisipasi aktif siswa dalam proses pembelajaran(Brame, 2016; Masitah, Pamungkasari and Suminah, 2020). Oleh Karena itu, penulis tertarik untuk mengalisis pengaruh edukasi gizi melalui media video Piring Makanku terhadap peningkatan pengetahuan dan sikap gizi seimbang pada remaja di SMP Negeri 1 Tumijajar.

\section{METODE PENELITIAN}

Penelitian ini dilakukan pada bulan September - Oktober 2020 di SMPN 1 Tumijajar Kabupaten Tulang Bawang Barat. Desain penelitian yang digunakan dalam penelitian ini adalah quasi experiment dengan satu kelompok sampel dan satu kelompok kontrol (two group pre and post test). Kelompok intervensi adalah kelompok yang diberikan media edukasi menggunakan video sedangkan kelompok control diberikan media edukasi berupa power point. Video tersebut menggunakan konsep yang dirancang oleh peneliti sendiri yang 
berisi materi tentang latar belakang kegemukan sebagai masalah gizi, penyebab dan bahaya kegemukan, serta isi piringku merupakan visualisasi gizi seimbang yang menggambarkan tentang anjuran porsi dalam setiap kali makan dengan memperhatikan prinsip keanekaragaman pangan, aktivitas fisik, perilaku hidup bersih dan memantau berat badan untuk mencegah masalah gizi.

Sampel pada penelitian ini adalah siswa yang berada dalam populasi yaitu siswa kelas IX dengan pengambilan sampel menggunakan cara random sampling yaitu pengalokasian jumlah kelompok intervensi dan kelompok kontrol diambil secara acak yang masing-masing kelompok berjumlah 30 siswa. Metode yang digunakan dalam intervensi adalah metode penyuluhan yaitu pemutaran media video gizi seimbang selama 7 menit sedangkan untuk kelompok kontrol menggunakan metode penyuluhan dengan power point. Data dianalisis mengunakan SPSS version 17 for windows. Uji Mann-Whitney digunakan untuk menganalisis perbedaan efektivitas edukasi gizi yaitu berupa video dan power point terhadap pengetahuan dan sikap siswa dalam memahami pedoman gizi seimbang. Penelitian sudah mendapatkan izin dan laik etik dari Komisi Etik Penelitian Kesehatan Poltekkes Kemenkes Tanjung Karang Etik Nomor: 259/KEPK-TJK/V/2020.

\section{HASIL DAN PEMBAHASAN PENELITIAN}

Sampel dalam penelitian ini adalah siswa kelas IX sebagai kelompok intervensi yang berjumlah 30 siswa dan IX sebagai kelompok kontrol 30 siswa sehingga total sampel adalah sebesar 60 siswa. Distiribusi frekuensi usia pada kelompok intervensi dan kontrol tidak jauh berbeda.

Tabel 1. Karakteristik Siswa Berdasarkan Kelompok Kontrol dan Intervensi

\begin{tabular}{|c|c|c|c|c|c|c|}
\hline \multirow{3}{*}{$\begin{array}{c}\text { Karakteristik } \\
\text { Siswa }\end{array}$} & \multicolumn{4}{|c|}{ Kelompok } & \multirow{2}{*}{\multicolumn{2}{|c|}{ Jumlah }} \\
\hline & \multicolumn{2}{|c|}{ Kontrol } & \multicolumn{2}{|c|}{ Intervensi } & & \\
\hline & $\mathbf{n}$ & $\%$ & $\mathbf{n}$ & $\%$ & $\mathbf{n}$ & $\%$ \\
\hline \multicolumn{7}{|l|}{ Usia } \\
\hline 13 & 0 & 0,00 & 2 & 6,7 & 2 & 100 \\
\hline 14 & 26 & 86,7 & 16 & 53,3 & 42 & 100 \\
\hline 15 & 4 & 13,3 & 10 & 33,3 & 14 & 100 \\
\hline 16 & 0 & 0,00 & 2 & 6,7 & 2 & 100 \\
\hline \multicolumn{7}{|l|}{ Jenis Kelamin } \\
\hline Laki-laki & 17 & 56,7 & 10 & 33,3 & 27 & 100 \\
\hline Perempuan & 13 & 43,3 & 20 & 66,7 & 33 & 100 \\
\hline \multicolumn{7}{|l|}{ Riwayat } \\
\hline \multicolumn{7}{|l|}{ Kegemukan } \\
\hline Ada & 10 & 33,3 & 7 & 23,3 & 17 & 100 \\
\hline Tidak & 20 & 66,7 & 23 & 76,6 & 43 & 100 \\
\hline
\end{tabular}

Berdasarkan tabel 1 menunjukan bahwa sebaran usia terendah 13 tahun, tertinggi 16 tahun, dan terbanyak pada usia 14 tahun yaitu pada kelompok intervensi 16 siswa (53,3\%) dan kontrol 26 siswa $(86,7 \%)$. Kelompok intervensi jumlah siswa terbanyak berjenis kelamin perempuan yaitu 20 siswa (66,7\%), sedangkan jumlah siswa pada kelompok kontrol siswa terbanyak laki-laki yaitu 17 siswa (56,7\%). Siswa yang mempunyai riwayat kegemukan pada keluarga antara kelompok intervensi dan kontrol tidak jauh berbeda. Diketahui pada kelompok intervensi ada sebanyak 7 siswa $(23,3 \%)$ yang mempunyai riwayat kegemukan dan pada kelompok kontrol ada 10 siswa (33,3\%). Anggota keluarga tersebut antara lain ayah, ibu, kakak, dan kakek. 
Tabel 2. Pengaruh Edukasi Gizi melalui Media Video dan Power Point Terhadap Pengetahuan dan Sikap Siswa

\begin{tabular}{|c|c|c|c|}
\hline \multirow[b]{2}{*}{ Kelompok } & \multicolumn{2}{|c|}{ Perlakuan } & \multirow[b]{2}{*}{$\mathbf{p}$} \\
\hline & $\begin{array}{l}\text { Sebelum Intervensi } \\
\text { Mean (min-max) }\end{array}$ & $\begin{array}{l}\text { Sesudah Intervensi } \\
\text { Mean (min-max) }\end{array}$ & \\
\hline \multicolumn{4}{|c|}{ Power Point (Kontrol) } \\
\hline Pengetahuan & $26,80(20-36)$ & $58,40(48-72)$ & 0,001 \\
\hline Sikap & $72,16(66-79)$ & $84,80(79-96)$ & 0,001 \\
\hline \multicolumn{4}{|c|}{ Video (Intervensi) } \\
\hline Pengetahuan & $27,06(20-36)$ & $79,2(32-92)$ & 0,001 \\
\hline Sikap & $72,30(65-79)$ & $86,26(80-96)$ & 0,001 \\
\hline
\end{tabular}

Promosi kesehatan merupakan salah satu tahap awal kehidupan dengan mendorong praktik makan sehat secara teratur yang berpotensi dan berdampak besar pada kesehatan selama masa anak-anak, remaja hingga tahap kehidupan selanjutnya(Lin and Dali, 2012). Pendidikan gizi berbasis sekolah harus mempertimbangkan kebutuhan dan minat siswa, guru dan sekolah. Strategi pendidikan gizi meliputi upaya peningkatan kesadaran kesehatan, komunikasi dan pengembangan keterampilan(Pérez-Rodrigo and Aranceta, 2003). Edukasi gizi merupakan promosi yang dirancang berdasarkan teori perilaku kesehatan yang berlaku, fokus pada beberapa perilaku terkait gizi yang dapat dimodifikasi, dan menangani berbagai mediator, seperti motivator dan hambatan yang relevan untuk bertindak dalam meningkatkan pengetahuan dan sikap seseorang. Efektifitas edukasi gizi juga dapat disesuaikan dengan desain intervensi serta strategi perubahan perilaku yang memiliki manfaat berkelanjutan bagi perubahan gaya hidup dalam peningkatan kesehatan (Yunianto et al., 2015; Dattilo and Saavedra, 2020).

Tabel 2 menunjukkan bahwa terdapat pengaruh yang signifikan efektivitas media edukasi gizi terhadap peningkatan pengetahuan dan sikap siswa. Kelompok Kontrol yang menggunakan media power point memiliki hubungan yang signifikan terhadap peningkatan pengetahuan dan sikap siswa. Hal ini sesuai dengan penelitian sebelumnya yang dilakukan oleh (Irnani and Sinaga, 2017) yang menunjukan bahwa media power point dapat meningkatkan pengetahuan serta praktik siswa mengenai gizi seimbang. Media power point merupakan salah satu media visual yang efektif yang dapat meningkatkan skor pengetahuan dan sikap dibandingkan dengan media visual lain seperti flip chat dan leaflet (Ekayanti, Briawan and Destiara, 2014).

Kelompok intervensi yang diberikan video piring makanku secara signifikan lebih tinggi dalam peningkatan pengetahuan dan sikap siswa. Berdasarkan nilai rata-rata menunjukan bahwa skor pengetahuan dan sikap siswa yang diberikan video jauh lebih tinggi dibandingakan dengan kelompok kontrol yang menggunakan media power point. Hal ini sejalan dengan penelitian sebelumnya oleh (Masitah, Pamungkasari and Suminah, 2020) yang menyatakan bahwa video memiliki pengaruh yang signifikan terhadap peningkatan pengetahuan. Video merupakan media yang menarik, efektif dan efisien yang memudahkan siswa memahami materi tentang gizi. Intervensi gizi melalui media video juga dapat meningakatkan sikap siswa akan kesehatan khususnya mengenai gizi seimbang(Asrori and Salam, 2020; Shapu et al., 2020; Wolf et al., 2020). Skor pengetahuan dan sikap tentang gizi memiliki kaitan yang sangat erat antara keduanya dan merupakan penentu perilaku pola makan remaja usia sekolah(Sharma et al., 2019). Selain itu, pemberian edukasi gizi memiliki pengaruh yang positif tentang gaya hidup sehat dan efektif sebagai intervensi kesehatan berbasis sekolah yang dapat mengubah perilaku makan sehat di masa depan (Kulik et al., 2019; Sharif Ishak et al., 2020).

\section{KESIMPULAN}

Pengetahuan dan sikap siswa baik kelompok intervensi dan kelompok control menunjukan peningkatan berdasarkan rata-rata skor. Edukasi gizi baik menggunakan media video dan power point secara signifikan efektif dalam meningkatkan pengetahuan dan sikap siswa. Namun, media video memiliki pengaruh yang lebih besar berdasarkan hasil rata-rata skor pengetahuan dan sikap dibandingkan dengan media power point.

\section{SARAN}

Saran dalam penilitian ini yaitu perlu adanya peningkatan pemberian edukasi gizi kepada siswa dari petugas gizi puskesmas bekerja sama dengan pihak sekolah berupa penyuluhan dengan menggunakan media berupa video piring makanku secara berkala guna meningkatkan pengetahuan dan sikap siswa terkait gizi seimbang. 
Petugas gizi dan sekolah perlu mengkombinasikan antara media vidio dengan berbagai media lainnya seperti leaflet, brosur dan metode ceramah menunjang alat bantu guru dalam proses belajar agar lebih efektif dalam meningkatkan pengetahuan dan sikap siswa tentang gizi seimbang. Penulis menyarankan penelitian lebih lanjut terkait pemberian edukasi gizi seimbang menggunakan media audio visual lainnya seperti social media, iklan, dan sebagainya untuk mengetahui media yang paling efektif guna meningkatkan pengetahuan dan sikap siswa terkait gizi seimbang.

\section{DAFTAR PUSTAKA}

Ajie, W., Muzaffar, H. and Chapman-Novakofski, K. (2014) 'Learning Through Online Videos in a Nutrition Education Intervention for Middle-School Students', Journal of Nutrition Education and Behavior, 46(4). doi: 10.1016/j.jneb.2014.04.022.

Asmuniati, L., Herawati, D. M. D. and Djais, J. T. B. (2019) 'The Impact of Nutritional Counseling to Nutritional Knowledge and Energy Intake among Obese Children in Junior High School', Althea Medical Journal, 6(3), pp. 107-109. doi: 10.15850/amj.v6n3.1645.

Asrori, A. and Salam, A. (2020) 'Pengaruh Edukasi Gizi Dengan Logbook Remaja Putri Anemia', Jurnal Gizi Prima, 5(September), pp. 96-102.

Brame, C. J. (2016) 'Effective educational videos: Principles and guidelines for maximizing student learning from video content', CBE Life Sciences Education, 15(4), p. es6.1-es6.6. doi: 10.1187/cbe.16-03-0125.

Crites, S. L. and Aikman, S. N. (2005) 'Impact of nutrition knowledge on food evaluations', European Journal of Clinical Nutrition, 59(10). doi: 10.1038/sj.ejen.1602231.

Dattilo, A. M. and Saavedra, J. M. (2020) 'Nutrition Education: Application of Theory and Strategies during the First 1,000 Days for Healthy Growth', in. doi: 10.1159/000499544.

Ekayanti, I., Briawan, D. and Destiara, I. (2014) 'Perbedaan Penggunaan Media Pendidikan Terhadap Perubahan Pengetahuan Dan Sikap Ibu Dalam Sarapan Anak Sekolah Dasar Di Kabupaten Bogor', Jurnal Gizi dan Pangan, 8(2), p. 109. doi: 10.25182/jgp.2013.8.2.109-114.

Epuru, S. and Shammary, M. U. H. Al (2014) 'Nutrition Knowledge and its Impact on Food Choices among the students of Saudi Arabia.', IOSR Journal of Dental and Medical Sciences, 13(1), pp. 68-74. doi: $10.9790 / 0853-13156874$

Febriana, R., Devi Artanti, G. and Rusilanti, R. (2020) 'The Effectiveness of Learning Videos for Increasing Knowledge about Women's Adolescent Nutrition and Reproductive Health', KnE Social Sciences, 2020, pp. 628-637. doi: 10.18502/kss.v4i14.7920.

Hudson, L. and Viner, R. M. (2012) 'Obesity in children and adolescents', BMJ, 345(sep25 2). doi: 10.1136/bmj.e5457.

Irnani, H. and Sinaga, T. (2017) 'Pengaruh pendidikan gizi terhadap pengetahuan, praktik gizi seimbang dan status gizi pada anak sekolah dasar’, Jurnal Gizi Indonesia (The Indonesian Journal of Nutrition), 6(1), pp. 58-64. doi: 10.14710/jgi.6.1.58-64.

Kamsiah, Emy Yuliantini, A. E. Y. (2020) 'Nutritional Education Model Through Crossword Puzzles Toward Knowledge And Macro Nutrient Intake Of Primary School Student In Bengkulu City', 11(10), pp. $722-725$.

Kemenkes RI (2014a) Laporan Nasional Riset Kesehatan Dasar 2013. Jakarta: Kementerian Kesehatan Republik Indonesia.

Kemenkes RI (2014b) Survei Konsumsi Makanan Individu Indonesia 2014. Jakarta: Badan Penelitian dan Pengembangan Kesehatan Kementerian Kesehatan Republik Indonesia. 
Kemenkes RI (2019) Laporan Nasional Riset Kesehatan Dasar 2018. Jakarta: Kementerian Kesehatan Republik Indonesia.

Kulik, N. L. et al. (2019) 'Knowledge, Attitudes, Self-Efficacy, and Healthy Eating Behavior Among Children: Results From the Building Healthy Communities Trial', Health Education \& Behavior, 46(4). doi: $10.1177 / 1090198119826298$.

Lin, L. P. and Dali, W. P. E. W. (2012) 'The impact of nutrition education interventions on the dietary habits of college students in developed nations: A brief review', Malaysian Journal of Medical Sciences, 19(1), pp. 4-14.

Lindberg, L. et al. (2020) 'Association of childhood obesity with risk of early all-cause and cause-specific mortality: A swedish prospective cohort study', PLoS Medicine, 17(3), pp. 1-14. doi: 10.1371/JOURNAL.PMED.1003078.

Made Darawati, A. E. Y. N. K. S. S. O. (2020) 'Stunting Prevention Through Participative Counselling on The Implementation of Balanced Nutrition Toward Children by Involving Local Puppeteers in Central Lombok Regency, West Nusa Tenggara', Systematic Reviews in Pharmacy, 11(11), pp. 805-810. doi: 10.31838/srp.2020.11.118.

Masitah, R., Pamungkasari, E. P. and Suminah, S. (2020) 'the Effectiveness of Animation Video To Increase Adolescents' Nutritional Knowledge', Media Gizi Indonesia, 15(3), p. 199. doi: 10.20473/mgi.v15i3.199204.

Pérez-Rodrigo, C. and Aranceta, J. (2003) 'Nutrition education in schools: experiences and challenges', European Journal of Clinical Nutrition, 57(S1), pp. S82-S85. doi: 10.1038/sj.ejen.1601824.

Shahsanai, A. et al. (2018) 'Assessment of the Relationship between Nutritional Knowledge and Anthropometric Indices in Isfahan Children and Adolescent', Advanced Biomedical Research, 7(1). doi: 10.4103/abr.abr_1_18.

Shapu, R. C. et al. (2020) 'Systematic review: Effect of health education intervention on improving knowledge, attitudes and practices of adolescents on malnutrition', Nutrients, 12(8), pp. 1-19. doi: $10.3390 /$ nu12082426.

Sharif Ishak, S. I. Z. et al. (2020) 'Effectiveness of a school-based intervention on knowledge, attitude and practice on healthy lifestyle and body composition in Malaysian adolescents', BMC Pediatrics, 20(1), pp. 112. doi: 10.1186/s12887-020-02023-X.

Sharma, S. et al. (2019) 'Relationships between nutrition-related knowledge, attitude, and self-efficacy among adolescents: A community-based survey', Journal of Family Medicine and Primary Care, 8(6). doi: 10.4103/jfmpc.jfmpc_217_19.

Weerasekara, P. C. et al. (2020) 'Food and nutrition-related knowledge, attitudes, and practices among reproductive-age women in marginalized areas in Sri Lanka', International Journal of Environmental Research and Public Health, 17(11), pp. 1-24. doi: 10.3390/ijerph17113985.

Wolf, P. G. et al. (2020) 'Educational video intervention improves knowledge and selfefficacy in identifying malnutrition among healthcare providers in a cancer center: a pilot study', Support Care Cancer, 28(2), pp. 683-689. doi: 10.1007/s00520-019-04850-w.Educational.

Yunianto, A. E. et al. (2015) 'Association Between Nutrition Knowledge and Nutritional Status with Blood Glucose Status in Rural Areas', Pakistan Journal of Nutrition, 14(9), pp. 603-610. doi: 10.3923/pjn.2015.603.610. 